\title{
Bliskie relacje na odległość w migranckich rodzinach chłopskich na początku XX wieku. Analiza serii listów Stelmachów
}

DOI: $10.19195 / 2083-7763.7 .8$

\section{Wstęp}

Proponowany artykuł został napisany w oparciu o wystąpienie warsztatowe, którego celem było zaprezentowanie metody/techniki analizy wybranego dokumentu pisanego, wskazanego uprzednio przez organizatorów konferencji ${ }^{1}$. Założeniem spotkania było interdyscyplinarne zgłębienie problemów badania pisanych dokumentów osobistych (pamiętnik, dziennik, list lub blog), traktowanych jako projekcje stanów świadomości oraz świadectw zjawisk społecznych, kulturowych, politycznych, językowych i innych.

Przedmiotem mojego zainteresowania była seria listów Jana i Ewy Stelmachów (Thomas, Znaniecki 1976, s. 289-298), a celem badawczym podjęcie próby ich analizy w prezentystycznym ujęciu koncepcyjnym, co rozumiem jako krytyczne spojrzenie na tekst sprzed ponad stu lat $\mathrm{z}$ punktu widzenia zjawisk i pojęć właściwych współczesności. W proponowanym szkicu stawiam pytanie o naturę bliskich, intymnych relacji w wybranej rodzinie chłopskiej z początku XX wieku, która została rozdzielona migracją i utrzymuje kontakt listowny.

Ze względu na skromność badanego materiału źródłowego, analiza i wnioski nie mają służyć za podstawę do sformułowania uogólnień dotyczących strategii bliskich relacji szeroko rozumianej warstwy chłopskiej, są natomiast propozycją spojrzenia na rodzinę chłopską (przez analizę korespondecji) w opozycji

1 Warsztat został przeprowadzony 11 grudnia 2015 r. we Wrocławiu podczas drugiej ogólnopolskiej interdyscyplinarnej konferencji z cyklu „Rzeczywistości kulturowe i teksty pisane” pt. „Dokumenty osobiste w socjologicznych i pozasocjologicznych doświadczeniach badawczych”. 
do funkcjonalno-strukturalnej roli, jaką często się jej przypisuje (por. Markowska 1976; Ignar 1986; Knapik 2013), i mogą stanowić przyczynek do dalszych eksploracji.

\section{Inspiracje teoretyczne}

W opracowaniach dotyczących chłopów polskich rodzina była zazwyczaj na marginesie zainteresowań badaczy (por. Inglot 1992), a jeśli już poświęcano jej uwagę, to dominującym sposobem jej przedstawienia był paradygmat funkcjonalno-strukturalny (Markowska 1976; Ignar 1986)² opisujący rodzinę i jej członków z perspektywy deterministycznej - paternalistycznych wspólnot o ściśle i jasno określonych rolach, funkcjonujących w obrębie dość hermetycznych społeczności wiejskich oraz wewnętrznym systemem kontroli społecznej i sankcji. Bliskość i intymność w relacjach rodzinnych, będące optyką tego artykułu, to pojęcia przypisywane zazwyczaj nowoczesnym relacjom rodzinnym, które stopniowo ewoluowały w nowoczesnych społeczeństwach przemysłowych, kiedy ziemia przestała być głównym źródłem pozyskiwania środków do życia dla mas wywodzących się z nieuprzywilejowanych warstw społecznych. Uprzednio „stosunki między małżonkami oraz rodzicami i dziećmi podporządkowane są [...] logice długiego trwania, dominującej nad logiką uczucią" (Marody, Giza-Poleszczuk 2004, s. 204). Rodzina chłopska traktowana była (nie zawsze słusznie) jako idealny typ rodziny tradycyjnej, której tożsamość ogniskowała się przede wszystkim wokół funkcji gospodarczych i gospodarstwa rolnego i cechowała ją m.in. „nierozerwalność związku małżeńskiego, zawieranego w wyniku grupowo-rodzinnej decyzji, a traktowanego jak instytucja sakralna, powołana do spłodzenia potomstwa i wspólnego osiągania celów gospodarczych" (Markowska 1976, s. 19). Rodzinę wiejską i relacje panujące w jej obrębie charakteryzowała hierarchiczność i duży pragmatyzm - role społeczne były jasno określone, podejmowane działania miały przynosić korzyść ekonomiczną wspólnocie, a miłość czy bliskość były ewentualnie wtórną i drugorzędną konsekwencją praktycznych kalkulacji i decyzji, które mogły, lecz nie musiały wykształcić się w toku trwania związku małżeńskiego. Z drugiej strony Ignar wskazuje, „że nie tylko socjologia, ale i opinia powszechna widzą we wsi coś biernego, coś, co tylko przeżywa i przeżuwa, a nie tworzy i nie dąży" (1986, s. 133), co wskazywałoby, że też w obrębie rodziny chłopskiej można doszukiwać się nie tylko cech konserwujących status quo, lecz także „pierwiastków dynamicznych" (ibidem), będących zalążkiem przyszłych zmian.

Wskutek postępującej industrializacji i urbanizacji oraz wzrostu znaczenia wartości i dążeń indywidualnych relacje natury emocjonalnej zaczęły częściowo

2 Celowo nie powołuję się na wcześniejsze monografie, jak chociażby J. Chałasiński, Młode pokolenie chłopów: procesy i zagadnienia kształtowania się warstwy chłopskiej w Polsce, t. 3 , Warszawa 1938, gdyż w dziełach z pierwszej połowy XX wieku nie dziwi przyjęcie takiej perspektywy teoretycznej. 
„wypierać" więzi o charakterze funkcjonalnym, a patriarchalne modele związków ewoluować w stronę relacji partnerskich (Bukraba-Rylska 2008, s. 139). Przeludnienie wsi oraz niedobór ziemi pozwalającej wyżyć z pracy rąk to dwa czynniki wypychające ludzi w sile wieku ze wsi, skutkujące migracją zarobkową. Nawet jeśli pierwotnym celem wyjazdu miała być jedynie poprawa sytuacji materialnej, aby dokonać inwestycji po powrocie w rodzinne strony, to doświadczenie życia i pracy poza hermetycznymi granicami rodziny, gospodarstwa i społeczności wiejskiej skutkowało transferem kulturowym i przyspieszało proces zmian społecznych.

Pojęcie intymność jest trudne w operacjonalizacji - mimo iż większość osób będzie intuicyjnie rozumieć, co ono znaczy, to z drugiej strony w kontekście związków międzyludzkich może przybierać wiele różnych znaczeń. Słowo ,intymność" pochodzi od łacińskiego słowa „intimus”, czyli „wewnętrzny, najgłębszy", i może odnosić się zarówno do werbalnego aspektu relacji, jak interakcja i komunikacja, jak i do pozawerbalnego, czyli dotyk, gest, mowa ciała, seks. Mówiąc o sferze intymnej w ujęciu historycznym, będzie się ją częściej odnosić do cielesności (por. Musiał 2013), podczas gdy współcześnie intymność to fenomen odwołujący się do relacyjności - wszystkich sposobów, za pomocą których ludzie podtrzymują swoje związki i więzi w różnych momentach i okolicznościach, razem ze wspomnieniami, uczuciami i poczuciem więzi z innymi (Giddens 2012). W niniejszym artykule bliskość i intymność będę rozumieć procesualnie, jako podtrzymywanie bliskich relacji, zaangażowanie w związek budowane w oparciu o wspólnotę przeżyć, wspomnień, doświadczeń, uczuć.

W proponowanym artykule i jego ujęciu koncepcyjnym stawiam pytanie o naturę bliskich, intymnych relacji w rodzinach chłopskich z początku XX w., które rozdzielone zostały migracją i utrzymują kontakt listowny.

\section{Metodologia i cele artykułu}

Ewa Morawska (2013) odnotowuje, że na przełomie XX i XXI wieku pośród badaczy przedmiotu panował konsensus odnośnie do tego, iż migracje z okresu sprzed I wojny światowej różniły się od współczesnych migracji stopniem zaangażowania $\mathrm{w}$ utrzymywanie relacji z niemigrującymi członkami rodzin w ojczyźnie. Morawska argumentuje, że w obrębie transferu dóbr ekonomicznych, w sferze obywatelsko-politycznej czy też społeczno-kulturowej, podobieństw między „starą" a "nową” falą migracji jest więcej, niż się zwykło potocznie uważać. Od końca lat osiemdziesiatych XX wieku wraz z wzrostem popularności paradygmatu transnarodowego, wierzono, że gwałtowny rozwój technologii komunikacyjnych (najpierw telefonicznej stacjonarnej, później internetowej) oraz względnie tanich i dostępnych środków transportu sprawia, iż relacje współczesnych migrantów z bliskimi w krajach pochodzenia są intensywniejsze i bardziej bogate $\mathrm{w}$ treść. 
Celem niniejszego artykułu jest prezentystyczne podejście do kwestii bliskich relacji w migranckich rodzinach chłopskich z początku XX wieku (co we wstępie do niniejszego artykułu definiuję jako krytyczną analizę dokumentów sprzed stulecia z perspektywy zjawisk i pojęć właściwych współczesności) na podstawie analizy serii dziesięciu listów Jana i Ewy Stelmachów (nr 58-67), pisanych w latach 1909-1914. Ostatni list pozbawiony jest wstępu i daty, jeden list pominięto w publikacji (jest tylko wzmianka, czego dotyczył) (Thomas, Znaniecki 1976, s. 289-298). Wybór tej konkretnej serii listów był podyktowany odgórnie przez organizatorów konferencji, a poniższa analiza jest propozycją krytycznego spojrzenia na tekst źródłowy z innej perspektywy teoretycznej i potraktowania owej korespondencji jako przykładu zalążka pewnych zjawisk społecznych uznawanych za powszechne i charakterystyczne dla migracji drugiej połowy XX wieku.

Odwołując się z jednej strony do paradygmatu funkcjonalno-strukturalnego, w obrębie którego zwykło się postrzegać „tradycyjną" rodzinę chłopską, a z drugiej - do paradygmatu transnarodowego oraz do współczesnych zjawisk i kategorii badawczych towarzyszących migracjom rodzin, spróbuję zaprezentować, jak rodzina Stelmachów, galicyjskich chłopów-rolników, starała się doświadczać wspólnie przestrzeni i uczuć ponad granicami, i odpowiedzieć na pytania badawcze:

1. Czy w korespondencji Jana i Ewy Stelmachów, chłopów-rolników z Galicji, z okresu 1909-1914, pisanej do syna Józefa i synowej Julki w Ameryce na długo przed rewolucją technologiczną, kiedy listy były jedynym medium kontaktu, możemy zaobserwować jakieś zawiązki strategii komunikacyjnych dotyczących relacji bliskiej, intymnej oraz czym jest intymność w wydaniu chłopskim?

2. Czy możemy traktować Stelmachów jako przykład prekursorów „rodziny światowej” (żyjącej ponad granicami)? (Beck, Beck-Gernsheim 2013)

\section{Analiza empiryczna}

Spis ludności z 1921 roku wykazał, że 38,1\% ludności wiejskiej ogółem w całej Polsce była niepiśmienna (Landy-Tołwińska 1961, s. 61). Analfabetyzm był zdecydowanie mniejszy na terenach zaboru pruskiego, czyli na ziemiach północnych i zachodnich (4,2\%), w Polsce centralnej i południowej było to ok. 32\% ludności, na wschodzie kraju zaś, na terenach byłego zaboru rosyjskiego, niepiśmienni stanowili prawie 65\% ogółu ludności (ibidem). W Galicji, skąd pochodzą autorzy analizowanych listów, w 1880 roku prawie $82 \%$ osób nie umiało czytać i pisać (Inglot 1992, s. 189), a 20 lat później, mimo wzrostu liczby szkół ludowych oferujących podstawową wiedzę, nadal 41,3\% dzieci i 55,2\% młodzieży nie uczęszczało na nauki (ibidem, s. 190).

Klasa chłopska, trudniąca się głównie rolnictwem w celu zaspokojenia własnych potrzeb bytowych, nie postrzegała edukacji jako priorytetetowej inwestycji - kapitał chłopa stanowiły morgi, dzieci (jako zabezpieczenie na starość) i żywy 
inwentarz. W związku z tym pisanie listów było zajęciem, które ludności wiejskiej sprawiało raczej trudność, wiązało się z wysiłkiem intelektualnym i przede wszystkim wymagało czasu, co w realiach życia na wsi i mnogości prac codziennych w obejściu oraz w polu było raczej zbytkiem. Jednak, co ze zdziwieniem odnotowują Thomas i Znaniecki, chłop polski „pisze liczne i długie listy [...] pisanie listów jest dla chłopa obowiązkiem społecznym o charakterze ceremonialnym" (1976, s. 238). W swym monumentalnym dziele badacze dokonują typologii listów chłopów ze względu na formę i funkcję, zaznaczając jednak, że wszystkie listy pisane przez chłopów można zaliczyć do nadrzędnej kategorii, którą określają „listem z pokłonami”. Definiują go jako list pisany do tymczasowo nieobecnego krewnego, którego celem jest „zamanifestowanie trwania, pomimo rozłąki, rodzinnej solidarności” (ibidem). Autorzy konstatują, że owa nowa potrzeba werbalizowania solidarności pojawiła się wraz z wzrostem mobilności wśród chłopów i migracji poza rodzinne miejscowości i była substytutem osobistych, bezpośrednich relacji - uprzednio „żaden pojedynczy człowiek nie był szczególnie zobowiązany do manifestowania własnych uczuć rodzinnych częściej niż inni, chyba że przy nadzwyczajnych okazjach” (ibidem). W obrębie „listu z pokłonami” Thomas i Znaniecki wyodrębnili pięć podkategorii ze względu na funkcje zastępcze, jakie list pełnił. Były to listy:

1. ceremonialne (opisujące ważne rodzinne wydarzenia, święta; często zastępujące przemówienia, mające „ożywić uczucia rodzinne”);

2. informujące (opisujące szczegóły życia codziennego — „zachowanie wspólnoty zainteresowań");

3. sentymentalne (mające za cel odrodzić na nowo uczucia jednostki - pisane nawet bez „ceremonialnej okazji”);

4. literackie (pisane wierszem — rodzaj zabawy, mającej na celu realizację estetyczno-artystycznych potrzeb);

5. dotyczące interesów (rodzaj listów o charakterze transakcyjnym).

Już na podstawie analizy powyższej klasyfikacji widać, że poza nadrzędną funkcją manifestowania rodzinnej solidarności, listy przejawiają też funkcję fatyczną i służą podtrzymaniu więzi, stanowią formę ekspresji uczuć. Nawet jeśli pierwotnym celem jest transfer informacji, to jest on umotywowany niemożliwością przekazania ich osobiście i chęcią utrzymania migrującego członka rodziny „na bieżąco”.

Korespondencja Jana i Ewy Stelmachów obejmuje dziesięć listów, z których dwa (nr 58 i 61) rozpoczynają się ceremonialnie od przemowy, jednak większość z nich otwierają bardziej osobiste formy adresatywne: „Drogie Dzieci!” (nr 60, 62, 63, 64 65, 66) lub „Drogi Synu!” (nr 59). W wielu ustępach rodzice uzewnętrzniają rodzicielskie emocje, jak troskę o zdrowie i samopoczucie syna i synowej za oceanem: 
Litujemy się nad tobą bardzo, że nie masz teraz zdrowia, a już ci pisałem, żebyś wyniósł się z tego Pittsburgha. [...] A ty, Julka, nie zamartwiaj się, bo chora jesteś ze zmartwienia. Dostaniesz nerwowej choroby, wtedy nie będziesz ani zdrowa ani chora i żaden doktor ci nie pomoże [...] (nr 63).

Oczywiście, można argumentować, że troska o zdrowie jest przejawem pragmatyzmu chłopskiego - zdrowie jest niezbędnym warunkiem wywiązywania się ze swych gospodarskich powinności, co też stary ojciec może, przekładając swoją perspektywę, uważać za niezbędny warunek powodzenia syna i synowej na emigracji. Również to, że jako ojciec daje synowi rady, jest zgodne $\mathrm{z}$ etosem patriarchy rodziny. Niemniej sposób, w jaki wyraża ową troskę („[1]itujemy się nad tobą bardzo"), wskazuje na bardziej emocjonalne podejście do kwestii, gdyż litość jest emocją wyrażającą współczucie. Co więcej, w innym fragmencie tego samego listu ojciec pisze: „Najzdrowsze życie jest na gospodarstwie, ale jeżeli nie macie zamiaru iść na gospodarstwo, to przynajmniej przenieście się, gdzie powietrze jest lepsze” (nr 63), czyli zakłada możliwość podmiotowego sprawstwa dzieci, tego, iż wybiorą formę życia inną niż tradycyjna. Niniejszym ojciec sankcjonuje wolną wolę syna i wyraża akceptację jego wyborów - cieszy się, kiedy syn donosi, że hoduje drób i świnię, ale nie wywiera wpływu na styl życia dzieci, snuje tylko plany, że może jak wnuki dorosną, to rodzina za oceanem wróci do korzeni i przeniesie się na farmę.

Rodzice wspominają też o swoich uczuciach, takich jak lęk: „Kiedy nie pisaliście przez tak długi czas, myśleliśmy o was rozmaite rzeczy” (ibidem) czy żal: „prosiłem cię, żebyś mi doradził [...] Nawet mi nie odpowiedziałeś” (nr 61). Ojciec, mimo iż wyżej w hierarchii, nie jest już jedynym źródłem mądrości życiowej - prosi syna o radę, i jest urażony brakiem odpowiedzi. W listach manifestuje się też duma i radość, że jednak ten kontakt obustronny jest zachowany mimo rozłąki, co wcale nie jest regułą: „oni [mowa o innej rodzinie - przyp. A.D.] mają dwóch synów w Ameryce i nie wiedzą, czy tamci są nawet żywi, bo nigdy do nich nie piszą" (nr 67). W liście nr 64 pada czułe, empatyczne wyznanie:

\footnotetext{
Zasmuciło nas to bardzo, ponieważ drogie dzieci, jeśli coś was smuci, nas też zasmuca, ponieważ kochamy was wszystkich jak siebie samych. Jeśli piszesz, że dobrze się wam powodzi i twojej małej żoneczce, naszej synowej, także, wtedy jesteśmy zadowoleni, nawet jeśli własna bieda nas przyciska, ponieważ widzimy, że chociaż my cierpimy biedę, przynajmniej jednak naszym dzieciom dobrze się powodzi.
}

Użycie przez rodziców zdrobniałych sformułowań, jak „mała żoneczka”, jest ciepłym zwrotem, pozytywnie nacechowanym emocjonalnie. Biorąc pod uwagę, że w kilku innych fragmentach ojciec apeluje do syna o nieprzysyłanie pieniędzy, aby nie padły łupem złodziei, wyznanie to ma charakter nie tylko pragmatyczny, lecz również emotywny, więziotwórczy. Uczucia rodziców i ich emocjonalna więź z dziećmi przejawia się też w apelach o regularne utrzymywanie kontaktu: „A nie zapominajcie o nas, ale odzywajcie się do nas tak długo, jak długo będziemy żyli” (nr 67). W przypisie do tego fragmentu Thomas i Znaniecki wskazują 
także na zmianę natury relacji w kontekście migracyjnym, ewoluującej od więzi grupowej do indywidualnej:

Stary człowiek przestaje być aktywnym członkiem rzeczywistej grupy rodzinnej, a staje się jednostką, której jedyne stosunki z rodziną to związki uczuciowe i związki krwi. Zobowiązania wobec niego, tak samo jak jego zobowiązania wobec reszty rodziny, przestają mieć charakter społeczny, a nabierają charakteru moralnego (Thomas, Znaniecki 1976, I: 298).

W powyższym fragmencie widać, że już w korespondencji z początku XX wieku da się odnotować zawiązki rodzicielskich postaw koncentrujących się nie tylko na obowiązkach wynikających z tradycji, lecz także na uczuciach, które w przyszłości będą ewoluować w stronę relacji opartych głównie na więzi i uczuciach.

$\mathrm{Na}$ emanacje postaw indywidualistycznych oraz oznak postępowości rodziny Stelmachów wskazują też autorzy opracowania. We wstępie do serii listów Stelmachów zwracają uwagę na takie aspekty jak: zaniechanie aktywnej kontroli nad synem (zezwolenie mu na życie po swojemu) i ograniczenie się do udzielania rodzicielskich rad, akceptacja wolnego wyboru dzieci, np. w kwestii ożenku, jak również w kwestii samorealizacji i urzeczywistniania pragnień dzieci w dążeniu do zdobycia lepszej pozycji na obczyźnie. Wolny wybór matrymonialny był ewidentnym pogwałceniem tradycji i w innych przypadkach, nawet jeszcze w latach sześćdziesiątych XX wieku, mógł skończyć się dotkliwymi sankcjami, łącznie z wykluczeniem ze społeczności (Wieruszewska 1971, s. 104, za: Bukraba-Rylska 2008, s. 147). Mimo iż mężczyźni cieszyli się nieco większą swobodą, jeśli chodzi o „prowadzenie się", i nie podlegali tak surowej ocenie moralnej jak panny (Markowska 1976, s. 57-58), to jednak „wybór współmałżonka nie mógł być i nie był prywatną sprawą dwojga młodych" (ibidem, s. 60), gdyż od statusu małżonka/małżonki zależała przyszłość gospodarstwa, traktowanego jako wartość międzypokoleniowa, więc starano się kojarzyć pary o podobnym statusie ekonomicznym. Co więcej, samo zawarcie związku małżeńskiego nie oznaczało automatycznego „wyswobodzenia się" spod kurateli rodzicielskiej. Markowska pisze, że często po ślubie rodzice oddawali dzieciom ziemię jedynie w użytkowanie wraz z promesą odziedziczenia jej w przyszłości i miało to za zadanie utrzymać młodych w posłuszeństwie wobec ojca i matki, co mogło trwać nawet 10-20 lat (1976, s. 49-51). Stefan Ignar wskazuje natomiast, iż migracja była niekiedy sposobnością do realizacji „pragnień i umożliwiała skojarzenie wielu małżeństw z miłości” (1986, s. 73).

Tak więc w miejsce „uporczywego trzymania się tradycji” (Thomas, Znaniecki 1976, s. 289) pojawia się większe zrozumienie, elastyczność, i do pewnego stopnia negocjowalność w relacji. Zamiast namawiać syna do powrotu na ojcowiznę, co byłoby przejawem egzekwowania przez ojca obowiązku syna (dzieci) wobec rodziców do zapewnienia im dożywocia, ojciec planuje wydać na emigrację kolejnego syna, a nawet może dwóch, co może oznaczać, że przedkłada dobro dzieci (nawet jeśli w wymiarze czysto pragmatyczno-ekonomicznym) nad swoją biedę. 
Kolejny przykład rady, którą ojciec daje synowi, a jednocześnie odsłania swój postępowy tok myślenia, jest fragment z listu nr 66: „Drogie dzieci, pracujcie i oszczędzajcie, ile tylko można, żebyście mieli jakąś pomoc na czarną godzinę, ponieważ człowiek na tym świecie jest niedoskonały i zawsze mu czegoś brak". Mimo wiążącej siły tradycji i rodziny ojciec wie i chce, by syn również wiedział, że w życiu rozsądniej liczyć na siebie, gdyż zła sytuacja ekonomiczna może uniemożliwić kultywowanie zwyczaju solidarności krewniaczej. Apeluje do niego: „nawet gdybyś chciał wracać do kraju. Nie ma tu dobroci. Ponieważ wiesz, ci, którzy byli z tobą, wrócili [...] i znów odjechali do Ameryki, bo mamy tu biedę" (nr 63). Z tonu listów wnioskuję, że ojciec nie zakłada powrotu syna, sam pisze, iż to jest mało realne: „Drogi synu, twoja matka byłaby rada, żeby mogła zobaczyć ciebie, zanim umrze, ale to trudna sprawa, ponieważ tutaj, w naszym kraju, robi się coraz gorzej [...] bieda wkrada się do domów i wypędza ludzi w świat" (nr 66).

W związku z tym ich relacja staje się bardziej partnerska niż hierarchiczna. Ojciec i matka mogą dać dzieciom za oceanem pozdrowienie, życzenia, opłatek, troskę i zapewnić o swojej miłości, a interesy jednostkowe dzieci powoli zaczynają przeważać nad interesem zbiorowym całej rodziny.

\section{Podsumowanie i wnioski}

„Dzieci są bogactwem chłopa”, jednak czynnik demograficzno-ekonomiczny "zmusił" ponad milion Galicjan do opuszczenia swoich wiosek w latach 18701910 (Chałasiński [w:] Thomas, Znaniecki 1976, s. 11) i podróży „za chlebem”, przeważnie do Ameryki. Na przełomie XIX i XX wieku „prawie 85\% całej emigracji zamorskiej z ziem polskich" przyjęły Stany Zjednoczone i w 1914 roku liczba polskich migrantów w USA wynosiła już trzy miliony (Markowska 1976, s. 25). Z pozostałych dwóch zaborów wyemigrowało równie dużo osób: z pruskiego $-1,2$ miliona, $\mathrm{z}$ rosyjskiego $-1,4$ miliona (Bukraba-Rylska 2008, s. 233). Ameryka dużo częściej była też celem migracji osiedleńczej (ibidem), chociaż niektórzy wybierali model migracji wahadłowej. Mimo wysokich kosztów, rekordziści „wyprawiali się za ocean nawet po 10 razy” (Guściora 1929, s. 73, za: Bukraba-Rylska 2008, s. 236). Decyzja o tym, który członek rodziny wyemigruje, nie była postanowieniem indywidualnym jednostki, lecz wyznaczała ją pozycja w rodzinie. Najczęściej wyjeżdżali młodzi mężczyźni, którzy nie mieli perspektyw odziedziczenia ojcowizny. Praca fizyczna na uchodźstwie miała pomóc w zdobyciu kapitału ekonomicznego potrzebnego do zainwestowania w kraju rodzinnym (o ile decydowano się na powrót) i nie wpływała na wzrost społecznych aspiracji jednostek - migranci wracali do swoich wiosek, inwestowali w ziemię i inwentarz, podejmowali na powrót swoje zajęcia, nie kwestionując istniejącej hierarchii społecznej. Z drugiej strony podróże za ocean wpływały na poszerzenie horyzontów chłopskich, a zdobyty kapitał i inwestycje poczynione na skutek migracji 
podnosiły poziom jednostki i jej rodziny w lokalnej społeczności (Bukraba-Rylska 2008, s. 239-250). Co więcej, długie pobyty poza granicami lokalnej społeczności zaburzały egalitaryzm wspólnoty losu - doświadczenie, treści światopoglądowe, środowisko, ideologia podlegały wpływom obcych kultur, a następnie były do pewnego stopnia przenoszone i wdrażane na grunt rodzimy, tworząc podwaliny przyszłych przemian. Praca zarobkowa poza gospodarstwem rodzinnym zwiększała samodzielność i sprawczość jednostki, co jednocześnie skutkowało osłabieniem rodziny jako grupy pierwotnej i stwarzało możliwość do przenikania nowych wartości (Markowska 1976, Morawska 2013).

Masowe migracje trwają nieprzerwanie od przeszło 150 lat (Castles, Miller 2011, s. 19), są udziałem zarówno rodzin, jak i jednostek, które w miejsce bezpośrednich interakcji „twarzą w twarz” (Goffman 2006) z niemigrującymi bliskimi wytwarzają inne, alternatywne formy komunikacji. Obfita korespondencja z niemigrującymi członkami rodzin w kraju pochodzenia, opracowana przez Williama Thomasa i Floriana Znanieckiego, i opublikowana w 5 tomach w latach 1918-1920, daje nam wgląd $w$ interakcyjne realia tych migracji oraz może posłużyć za punkt odniesienia do analiz migracji współczesnych. W XXI wieku różnorodność układów rodzinnych, jak np. rodziny światowe, multilokalne $e^{3}$, których wzrost wydaje się być czymś charakterystycznym dla społeczeństw ponowoczesnych, jest w istocie odkryciem na nowo funkcjonujących niegdyś modeli familijnych ${ }^{4}$ (Beck, Beck-Gernsheim 2013). Natomiast na wsi nie było niczym rzadkim, że bezdzietne małżeństwa odciążały wielodzietnych krewnych (także osoby niespokrewnione, ale z tej samej parafii), biorąc na wychowanie ich dziecko/dzieci (Markowska 1976, s. 72). W prezentystycznym ujęciu przypadku rodziny Stelmachów (jak i wielu innych migrantów zarobkowych z przełomu XIX i XX wieku) można postawić hipotezę, że stali się oni częścią „rodziny światowej” $\mathrm{w}$ „wyniku nadziei uniknięcia biedy i bezrobocia w ojczyźnie” (ibidem, s. 21), żyjąc ponad granicami, utrzymując regularny (jak na owe czasy) kontakt listowny z dziećmi. Jak wskazują Marody i Giza-Poleszczuk, rodzina nie jest wbrew powszechnemu mniemaniu biernym odbiorcą szerszych zmian społecznych, lecz aktywnym uczestnikiem i kreatorem tych zmian (2004, s. 189), a odwołując się do pracy angielskiego badacza historii rodziny, Davida Levina, cytują, że:

3 Beck i Beck-Gernsheim definiują rodziny światowe jako te, które „żyją razem ponad granicami (narodowymi, religijnymi, kulturowymi, etnicznymi, itd.); w których współgra ze sobą to, co zgodnie z przyjętą definicją współgrać nie powinno. [...] Można wyróżnić dwa podstawowe typy. Przez pojęcie miłości na odległość i rodziny światowej rozumiemy, po pierwsze, pary czy rodziny, które żyją ze sobą w różnych krajach bądź nawet na różnych kontynentach, lecz należą do wspólnej kultury pochodzenia (język, paszport, religia) - to multilokalne rodziny światowe. [...] po drugie [...] to takie pary czy rodziny, które mieszkają w tym samym miejscu, ale których członkowie pochodzą z różnych krajów czy kontynentów" (2013, s. 30).

${ }^{4}$ Niemieccy socjologowie argumentują, że nie tylko migracje były powodem życia rodzin w separacji geograficznej - w Europie, $\mathrm{z}$ historycznego punktu widzenia, praktyki rodzinne szlachty i zamożnego mieszczaństwa także częściowo były sprawowane na odległość (ibidem). 
rodzina plebejska nie była po prostu przedmiotem, ale wprost przeciwnie: jej demograficzne zachowania, podejmowane w odpowiedzi na oddziaływania różnorakich presji ekonomicznych, stworzyły nowe warunki, które dogłębnie zmieniły historię (ibidem).

Morawska (2013) wskazuje też na wiele innych analogii między „starą”, dziewiętnastowieczną, falą migracji a „nową" z przełomu XX i XXI wieku. Czynniki ekonomiczne nadal są głównym motorem wypychającym masy z krajów pochodzenia w poszukiwaniu lepszych warunków bytowych lub możliwości zgromadzenia kapitału na inwestycje w kraju. Obie „fale” łączy też wysokie poczucie obowiązku i zobowiązanie wobec rodzin pozostawionych w kraju pochodzenia, które są wspierane finansowo z zagranicy (ibidem). Także w obrębie transferu symboliczno-kulturowego widać, że to, co intuicyjnie może wydawać się tożsame z czasami współczesnymi, miało już swoje przejawy w czasach opisywanych przez Znanieckiego. „Migracja jako norma społeczna i oczekiwania kulturowe” (ibidem) objawia się już w listach poprzez dyskusje na temat łańcuchów migracyjnych w obrębie federacji rodzin we wsi czy też organizacji w skupiskach migracyjnych na wychodźctwie. Jan Stelmach żegna syna słowami „Gud Baj”, naśladując syna, który przyczynia się do rozszerzenia świata społecznego swoich rodziców we wsi galicyjskiej. W powyższym rozumieniu możemy stwierdzić, że wychodźstwo chłopów i masowe migracje za ocean były przyczynkiem do powstania kilka dekad później multilokalnych rodzin światowych. Mimo iż Stelmachowie nie są z pewnością świadomymi prekursorami późniejszych trendów, to ich przykład pokazuje, że dzieląca odległość oraz technologiczne bariery komunikacyjne nie wpływają na dezintegrację związku rodzinnego.

W kwestii relacji z rodziną, biorąc pod uwagę ograniczenia spowodowane dostępnymi środkami komunikacji i transportu, nie możemy mówić o wypracowaniu zaawansowanych strategii utrzymywania kontaktu. Jednak mimo utrudnień rodzina Stelmachów korzysta aktywnie z tych im dostępnych — piszą dość regularnie listy (w opublikowanej korespondencji listy datowane są różnie - najkrócej co 2 miesiące, najdłużej co 9), w których demonstrują bogaty wachlarz znaczeń: dają przykład chłopskiemu pragmatyzmowi (informują co się dzieje w gospodarstwie i w okolicy), manifestują solidarność i więzi z rodziną (załączają np. dopisane pozdrowienia od innych krewnych), ale też wykazują bardzo „współczesne” uczucia, jak empatię, m.in. przez współczucie wywołane złym stanem zdrowia dzieci, przykaz dbania o siebie, troskę o zapewnienie dzieciom lepszego bytu (apele: pracujcie i oszczędzajcie, szanujcie pieniądze, udzielanie rad na odległość), lecz również miłość i emocjonalne przywiązanie przez zwracanie się do dzieci w sposób bezpośredni, czuły, zdrobniały, deklaracje i prośby o utrzymywanie kontaktu. Bliskość, intymność w wydaniu chłopskim jest w dużej mierze zakorzeniona w solidarności i o ile w przeciwieństwie do relacji współczesnych repertuar możliwości na podtrzymywanie relacji bliskiej jest ograniczony, o tyle można już w listach Stelmachów odnotować zalążki zaangażowania $\mathrm{w}$ relacje $\mathrm{z}$ dziećmi, budowaną 
w mniejszym stopniu w oparciu o wspólnotę przeżyć, ale odwołującą się do wspomnień, wspólnych światów znaczeń i uczuć.

\section{Bibliografia}

Beck U., Beck-Gernsheim E., Miłość na odległość. Modele życia w epoce globalnej, przeł. M. Sutowski, Warszawa 2013.

Bukraba-Rylska I., Socjologia wsi polskiej, Warszawa 2008.

Castles S., Miller M.J., Migracje we współczesnym świecie, przeł. A. Gąsior-Niemiec, Warszawa 2011.

Chałasiński J., Młode pokolenie chłopów: procesy i zagadnienia kształtowania się warstwy chłopskiej w Polsce, t. 3, Warszawa 1938.

Giddens A., Socjologia, Warszawa 2012.

Goffman E., Porzadek interakcyjny, [w:] Współczesne teorie socjologiczne, t. 1, red. A. Jasińska-Kania et al., Warszawa 2008.

Guściora F., Trzy Kurzyny: wsie powiatu niskiego, Puławy 1929.

Historia Chłopów Polskich, red. S. Inglot, Wrocław 1992.

Ignar S., Rodzina chłopska i gospodarstwo rolne, Warszawa 1986.

Knapik S., Charakter więzi rodzinnych we wspótczesnej rodzinie wiejskiej na podstawie wybranych wskaźników zastosowanych w badaniach własnych, „Wieś i Rolnictwo” 2013, nr 1.

Landy-Tołwińska J., Analfabetyzm z Polsce i na świecie, Warszawa 1961.

Markowska D., Rodzina w społeczności wiejskiej - ciagłość i zmiana, Warszawa 1976.

Marody M., Giza-Poleszczuk A., Przemiany więzi społecznych, Warszawa 2004.

Morawska E., The impact of past and present immigrants' transnational engagements on their homecountry localities: exploring an underinvestigated aspect of the transnationalism-migration relationship, „Studia Migracyjne - Przegląd Polonijny” 2013, nr 1.

Musiał M., Od obyczaju do kompulsji - wokół przemian intymności, „Kultura i Historia” 2013, nr 23, http://www.kulturaihistoria.umcs.lublin.pl/archives/4606 [dostęp: 26.06.2014].

Szlendak T., Socjologia rodziny, Warszawa 2010.

Wieruszewska M., Sankcje systemu kontroli społecznej wobec rodziny wiejskiej: na przykładzie dwóch wybranych wsi powiatu bełchatowskiego, Łódź 1971.

Znaniecki F., Thomas W., Chłop Polski w Europie i Ameryce, t. 1, Warszawa 1976.

\section{Close relationships at a distance among migrating peasant family members at the beginning of the 20th century. An analysis of the Stelmach Series of Letters}

\section{Summary}

In the proposed article and its demonstrative approach, I put the question about the nature of close, intimate relationships in peasant families from the early twentieth century, which were separated by migration and maintained contact with their children through letters, with reference to the series of letters of John and Eve Stelmach (taken from The Polish Peasant in Europe and America by Thomas and Znaniecki). Referring to the paradigm of transnationalism, modern phenomena and research categories associated with migration of families, I try to show how the Stelmach family, Galician peasant farmers, tried to experience togetherness and feelings across the borders in the pre-technology era. 